\title{
The effect of hexoestrol implantation on growth and certain carcass characteristics of fattening steers
}

\author{
By J. N. AITKEN AND J. A. CRICHTON \\ Rowett Research Institute, Bucksburn, Aberdeenshire \\ (Received 13 Fanuary I956)
}

A review of the literature shows that the subcutaneous implantation of stilboestrol increases rate of gain in weight and efficiency of food conversion in lambs (Andrews, Beeson \& Harper, 1949; Jordan, 1950; Perry, Andrews \& Beeson, I951; O'Mary, Pope, Wilson, Bray \& Casida, 1952; Means, Andrews \& Beeson, 1953) and in cattle (Clegg \& Cole, 1954). The oral administration to fattening steers of stilboestrol, hexoestrol or dienoestrol gives similar results (Culbertson, Burroughs, Kastelic, Hammond \& Cheng, I954; Shanks, 1955; Perry, Beeson, Andrews \& Stob, 1955). Hormone treatment, however, reduces carcass quality (Jordan, 1950, 1953; O'Mary et al. 1952; Andrews \& Beeson, 1953; Clegg \& Cole, 1954; Perry et al. 1955). Lower carcass grade in treated animals is due mainly to less fat covering over the carcass. Sometimes the meat may look dark red and slightly coarse and the carcasses appear to be heavy over the shoulder and neck regions and light in the loins. Undesirable side-effects such as elevation of the tail-head and excessive development of mammary tissue may occur. These changes tend to disappear by the end of 90 days after treatment (Clegg \& Cole, r954).

Published reports on the composition of the increase in live-weight gain are sparse and sometimes contradictory. There are reports of increased nitrogen retention, probably in the form of protein, in both sheep and cattle (Jordan, 1953; Whitehair, Willis $\&$ Bell, I953; Clegg \& Cole, 1954). On the other hand, the weight of muscle in sample cuts from control and treated wether lambs in one experiment showed no significant difference (O'Mary et al. 1952). Greater bone growth has also been reported (Dinusson, Andrews \& Beeson, 1950; O'Mary et al. 1952). The subcutaneous fat of treated animals had been shown to contain more water (O'Mary et al. I952).

These results have been obtained only under a rather restricted set of farming conditions. The quality and nature of the roughage portion of the diet has been shown to influence significantly the response to hormone treatment. Steers and heifers on irrigated pasture without supplementary feeding did not increase in weight more than control groups (Clegg \& Cole, I954). In a field trial with 9000 lambs implanted with stilboestrol and fed on maize and poor-quality hay, 2000 died, mainly as a result of prolapse of the uterus and rectum (Jordan, 1953).

The object of the present experiment was to determine the effects of hexoestrol implantation on steers given a winter fattening ration consisting of roots, silage, straw and concentrates. 


\section{EXPERIMENTAL}

Five pairs of $2 \frac{1}{2}$-year-old identical twin steers (three pairs of Cross Shorthorn and two pairs of Cross Friesian) were used. Uniformity trials with such twins have shown their superiority for research purposes over groups of unrelated animals, particularly in experiments where rate of gain in weight is an important consideration (King \& Donald, I955; Hancock, 195 I). All animals were offered the same rations. The maximum daily allowance per head averaged $35 \mathrm{lb}$. good-quality grass silage, $50 \mathrm{lb}$. swede turnips, Io $\mathrm{lb}$. oat straw and 4 rising to $7 \mathrm{lb}$. of a concentrate mixture consisting of eight parts oats, nine parts barley and three parts groundnut meal. The ratio of roughage to concentrates was approximately $12: \mathrm{I}$ by weight. Food intakes were recorded. One member of each pair was implanted with eight $15 \mathrm{mg}$ pellets of hexoestrol in the loose skin behind the left ear. The untreated member served as control. The implantations were made at the beginning of the last $3-4$ months of the fattening period. Both members of each pair were slaughtered on the same day.

A sample cut was taken from the right side of the carcass of each of one twin pair (no. $40 \mathrm{~A}$ and B). The cut included the ninth, tenth and eleventh ribs, and was made by cutting close to the rear edges of the eighth and eleventh ribs in accordance with the method described by Hankins \& Howe (1946). The samples were analysed for fat, protein and moisture. From these analyses the composition of the dressed carcass was estimated by means of regression equations calculated by Hankins \& Howe.

\section{RESULTS}

Live-weight gain. As can be seen from Table $\mathrm{I}$, there was a considerable variation between pairs of twins in the length of time required to complete the fattening for market. The gain in weight of the treated member of each twin pair was significantly

Table I. Within-twin pair comparison of total and mean daily live-weight gains of steers treated with hexoestrol and of untreated steers

\begin{tabular}{|c|c|c|c|c|c|c|c|}
\hline Pair no. & Breed & $\begin{array}{c}\text { Time on } \\
\text { experiment } \\
\text { (days) }\end{array}$ & $\begin{array}{c}\text { Initial } \\
\text { weight } \\
\text { (lb.) }\end{array}$ & $\begin{array}{c}\text { Final } \\
\text { weight } \\
\text { (lb.) }\end{array}$ & $\begin{array}{l}\text { Total } \\
\text { gain } \\
\text { (lb.) }\end{array}$ & $\begin{array}{l}\text { Excess total } \\
\text { gain of } \\
\text { treated } \\
\text { animal over } \\
\text { control } \\
\text { (1b.) }\end{array}$ & $\begin{array}{l}\text { Daily } \\
\text { gain } \\
\text { (lb.) }\end{array}$ \\
\hline $\begin{aligned} 32: & A, \text { treated } \\
& B, \text { untreated }\end{aligned}$ & Cross Shorthorn & $\begin{array}{l}76 \\
76\end{array}$ & $\begin{array}{l}\text { I I I } 4 \\
\text { I I } 64\end{array}$ & $\begin{array}{l}1302 \\
1312\end{array}$ & $\begin{array}{l}188 \\
148\end{array}$ & 40 & $\begin{array}{l}2 \cdot 47 \\
1 \cdot 94\end{array}$ \\
\hline $\begin{aligned} 34: & \text { A, treated } \\
& B \text {, untreated }\end{aligned}$ & Cross Friesian & $\begin{array}{l}77 \\
77\end{array}$ & $\begin{array}{l}\text { I } 315 \\
\text { I } 291\end{array}$ & $\begin{array}{l}1507 \\
1434\end{array}$ & $\begin{array}{l}192 \\
143\end{array}$ & 49 & $\begin{array}{l}2.50 \\
1.85\end{array}$ \\
\hline $\begin{aligned} 38: & A, \text { treated } \\
& B, \text { untreated }\end{aligned}$ & Cross Shorthorn & $\begin{array}{l}104 \\
104\end{array}$ & $\begin{array}{l}1236 \\
1272\end{array}$ & $\begin{array}{l}1404 \\
1384\end{array}$ & $\begin{array}{l}\text { r68 } \\
\text { I I } 2\end{array}$ & $5^{6}$ & $\begin{array}{l}I \cdot 6 I \\
I \cdot 07\end{array}$ \\
\hline $\begin{array}{l}\text { 40: } A \text {, treated } \\
B \text {, untreated }\end{array}$ & Cross Friesian & $\begin{array}{l}9 r \\
9 r\end{array}$ & $\begin{array}{l}\text { I I } 80 \\
\text { II } 72\end{array}$ & $\begin{array}{l}1365 \\
1288\end{array}$ & $\begin{array}{l}I 85 \\
I 16\end{array}$ & 69 & $\begin{array}{l}2 \cdot 03 \\
1 \cdot 27\end{array}$ \\
\hline $\begin{aligned} 47: & \text { A, treated } \\
& \text { B, untreated }\end{aligned}$ & Cross Shorthorn & $\begin{array}{l}70 \\
70\end{array}$ & $\begin{array}{l}1028 \\
1058\end{array}$ & $\begin{array}{l}\text { I I } 84 \\
\text { I I } 94\end{array}$ & $\begin{array}{l}\text { I56 } \\
\text { I } 36\end{array}$ & 20 & $\begin{array}{l}2 \cdot 22 \\
1 \cdot 94\end{array}$ \\
\hline Mean & ifference & & -16 & +30 & & 46 & $\begin{array}{l}0.56 \pm \\
0.08 *\end{array}$ \\
\hline
\end{tabular}

* Value with its standard error. 
higher $(P<0.01)$ than that of the control. The difference in total gain ranged from $20 \mathrm{lb}$. in pair no. $47 \mathrm{~A}$ and $\mathrm{B}$ to $69 \mathrm{lb}$. in pair no. $40 \mathrm{~A}$ and $\mathrm{B}$.

Food consumption and utilization. Comparisons of daily food intake between the members of each pair of twins showed no significant difference between treated and control animals (Table 2). Mean daily consumption of dry matter was $2 \mathrm{r} \cdot \mathrm{Olb}$. for the control and $2 \mathrm{I} \cdot 6 \mathrm{lb}$. for the treated steers. The greater gains in weight of the latter must therefore have been due to increased efficiency of food utilization. The greatest difference in efficiency of food conversion was noted in pair no. $38 \mathrm{~A}$ and $\mathrm{B}$ and the least in pair no. $47 \mathrm{~A}$ and $\mathrm{B}$. The differences between pairs of twins show that considerable variation in response to hormone treatment may be expected.

Table 2. Within-twin pair comparisons of food consumption and efficiency of food utilization of steers treated with hexoestrol and of untreated steers

\begin{tabular}{|c|c|c|c|c|c|c|c|c|}
\hline \multirow[b]{2}{*}{ Pair no. } & \multicolumn{4}{|c|}{ Daily food consumption (lb.) } & \multirow{2}{*}{$\begin{array}{l}\text { Total } \\
\text { food } \\
\text { consump- } \\
\text { tion* } \\
\text { (lb.) }\end{array}$} & \multirow{2}{*}{$\begin{array}{c}\text { Dry } \\
\text { matter } \\
- \text { eaten } \\
\text { daily } \\
\text { (lb.) }\end{array}$} & \multirow{2}{*}{$\begin{array}{c}\text { Total } \\
\text { digestible } \\
\text { nutrients } \\
\text { (TDN) eaten } \\
\text { daily } \\
\text { (lb.) }\end{array}$} & \multirow{2}{*}{$\begin{array}{l}\text { Efficiency } \\
\text { of food } \\
\text { utilization } \\
\text { (lb. TDN/lb. } \\
\text { gain) }\end{array}$} \\
\hline & $\begin{array}{l}\text { Concen- } \\
\text { trates }\end{array}$ & Silage & Turnips & Straw & & & & \\
\hline $\begin{aligned} 32: & \text { A, treated } \\
& B \text {, untreated }\end{aligned}$ & $\begin{array}{l}5 \cdot 63 \\
5 \cdot 63\end{array}$ & $\begin{array}{l}30 \cdot 4 \\
33 \cdot 5\end{array}$ & $\begin{array}{l}46 \cdot 8 \\
46 \cdot 8\end{array}$ & $\begin{array}{l}6 \cdot 7 \\
4 \cdot 9\end{array}$ & $\begin{array}{l}6804 \\
6827\end{array}$ & $\begin{array}{l}22 \cdot 0 \\
21 \cdot 2\end{array}$ & $\begin{array}{l}\text { I } 4 \cdot 2 \\
\text { I } 3 \cdot 2\end{array}$ & $\begin{array}{l}5 \cdot 7 \\
6 \cdot 8\end{array}$ \\
\hline $\begin{aligned} 34: & B \text {, treated } \\
& \text { A, untreated }\end{aligned}$ & $\begin{array}{l}5 \cdot 64 \\
5 \cdot 64\end{array}$ & $\begin{array}{l}33 \cdot 24 \\
32 \cdot 70\end{array}$ & $\begin{array}{l}46 \cdot 9 \\
46 \cdot 9\end{array}$ & $\begin{array}{l}7 \cdot 2 \\
5 \cdot 9\end{array}$ & $\begin{array}{l}7159 \\
7018\end{array}$ & $\begin{array}{l}23 \cdot 2 \\
21 \cdot 9\end{array}$ & $\begin{array}{l}14 \cdot 9 \\
14 \cdot 3\end{array}$ & $\begin{array}{l}6 \cdot 0 \\
7 \cdot 7\end{array}$ \\
\hline $\begin{array}{l}38: \mathrm{B}, \text { treated } \\
\quad \mathrm{A}, \text { untreated }\end{array}$ & $\begin{array}{l}5.99 \\
5.99\end{array}$ & $\begin{array}{l}31 \cdot 90 \\
33 \cdot 50\end{array}$ & $\begin{array}{l}48 \cdot 0 \\
48 \cdot 3\end{array}$ & $\begin{array}{l}4 \cdot 7 \\
4 \cdot 6\end{array}$ & $\begin{array}{l}9421 \\
9608\end{array}$ & $\begin{array}{l}2 I \cdot 3 \\
2 I \cdot 6\end{array}$ & $\begin{array}{l}14 \cdot 3 \\
14.5\end{array}$ & $\begin{array}{r}8 \cdot 3 \\
\times 3.5\end{array}$ \\
\hline $\begin{array}{l}40: \text { B, treated } \\
\text { A, untreated }\end{array}$ & $\begin{array}{l}6 \cdot 70 \\
6 \cdot 50\end{array}$ & $\begin{array}{l}24 \cdot 0 \\
22 \cdot 8\end{array}$ & $\begin{array}{l}40.9 \\
40.0\end{array}$ & $\begin{array}{l}4 \cdot 2 \\
3 \cdot 4\end{array}$ & $\begin{array}{l}6898 \\
66 I 6\end{array}$ & $\begin{array}{l}19 \cdot 3 \\
18 \cdot 1\end{array}$ & $\begin{array}{l}13.5 \\
12.8\end{array}$ & $\begin{array}{r}6 \cdot 6 \\
10 \cdot 1\end{array}$ \\
\hline $\begin{aligned} 47: & \text { A, treated } \\
& B \text {, untreated }\end{aligned}$ & $\begin{array}{l}6 \cdot 60 \\
6 \cdot 60\end{array}$ & $\begin{array}{l}25 \cdot 3 \\
26 \cdot 5\end{array}$ & $\begin{array}{l}42 \cdot 3 \\
42 \cdot 3\end{array}$ & $\begin{array}{l}477 \\
4 \cdot 2\end{array}$ & $\begin{array}{l}55^{2} 3 \\
5572\end{array}$ & $\begin{array}{l}20 \cdot 2 \\
20 \cdot 1\end{array}$ & $\begin{array}{l}14.0 \\
14.0\end{array}$ & $\begin{array}{l}6 \cdot 3 \\
7 \cdot 2\end{array}$ \\
\hline \multicolumn{5}{|c|}{ Mean difference } & $+33+$ & $+0.6 \pm 0.3$ & +0.4 & $-2.4^{8} \pm 0.8 \dagger$ \\
\hline
\end{tabular}

Carcass grade and dressing out percentage. Table 3 shows the carcass grades, carcass weights and dressing out percentages. The dressing out percentage is the weight, as a percentage of the live weight at slaughter, of the cold dressed carcass after bleeding and the removal of the feet, head, hide, abdominal viscera, lungs, liver, heart, windpipe, and the thyroid and thymus glands.

There was no significant difference between the treated and untreated animals in dressing out percentage. Hence the mean carcass weight of the treated animals was greater because of their greater live weight before slaughter. In four pairs there was no difference in carcass grade as determined by graders of the Fatstock Marketing Corporation. In one pair (no. $34 \mathrm{~A}$ and $\mathrm{B}$ ) the control animal was grade $\mathrm{A}$ and its mate was grade B owing to lack of finish, mainly fat deficiency.

Behaviour and body conformation. In the first 2 weeks after hexoestrol implantation the treated steers were the more restless and lost some weight. Changes in mammary 
Table 3. Within-twin pair comparison of carcass weight, dressing out percentage* and carcass grade of steers treated with hexoestrol and of untreated steers

\begin{tabular}{|c|c|c|c|}
\hline Pair no. & $\begin{array}{c}\text { Carcass } \\
\text { weight } \\
\text { (lb.) }\end{array}$ & $\begin{array}{l}\text { Dressing out } \\
\text { percentage* }\end{array}$ & $\begin{array}{c}\text { Carcass } \\
\text { grade }\end{array}$ \\
\hline 32: A, treated & 736 & 57.7 & A \\
\hline B, untreated & $75 I$ & $58 \cdot 4$ & A \\
\hline $34: B$, treated & 802 & $54 \cdot 2$ & B \\
\hline A, untreated & 780 & $55 \cdot 5$ & A \\
\hline $38: B$, treated & 815 & $56 \cdot 3$ & $\mathrm{~B}$ \\
\hline A, untreated & 803 & $56 \cdot 8$ & B \\
\hline $40: \mathrm{B}$, treated & 780 & $58 \cdot 2$ & B \\
\hline$A$, untreated & 737 & $58 \cdot 6$ & $B$ \\
\hline 47: A, treated & 676 & $58 \cdot 5$ & B \\
\hline $\mathrm{B}$, untreated & 669 & $57 \cdot 4$ & B \\
\hline Mean difference & +14 & $-0.3 \pm 0.4 \dagger$ & - \\
\hline
\end{tabular}

tissue and pelvis occurred in all treated animals in the first 3 weeks. Marked elevation of the tail-head and increases in rudimentary teat length were noted.

Carcass composition. The composition of the rib cuts from pair no. $40 \mathrm{~A}$ and $\mathrm{B}$ and the computed percentages of bone, fat, protein and moisture in the carcasses are shown in Table 4. The cut from the carcass of the treated steer had higher percentages of bone, protein and moisture and a lower percentage of fat than the cut from the carcass of the control. The estimates of the composition of the whole carcass showed that the carcass of the treated steer also had higher percentages of bone, protein and moisture, and a lower percentage of fat, than that of the control. The difference in the percentage of fat was of the same order as that found in the sample cuts. The differences in the other three constituents were slightly less in the carcasses than in the cuts.

Table 4. Percentage composition of the edible portion of the rib cuts from pair no. $40 \mathrm{~A}$ and $\mathrm{B}$ together with percentage weight of bone in whole cuts, and corresponding computed values for the edible portion of the dressed carcasses and for the bone in the whole carcasses

\begin{tabular}{|c|c|c|c|c|}
\hline 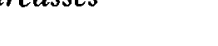 & \multicolumn{3}{|c|}{ Edible portion } & \multirow[b]{2}{*}{$\begin{array}{c}\text { Whole cut } \\
\text { Bone }\end{array}$} \\
\hline Pair no. & Moisture & $\begin{array}{l}\text { Crude } \\
\text { protein }\end{array}$ & Fat & \\
\hline \multicolumn{5}{|c|}{ Rib cuts } \\
\hline $\begin{array}{l}\text { 40: } \text { A, treated } \\
\text { B, untreated }\end{array}$ & $\begin{array}{l}45^{\cdot} 5 \\
43^{\cdot 2}\end{array}$ & $\begin{array}{l}13 \cdot 5 \\
13 \cdot 1\end{array}$ & $\begin{array}{l}40 \cdot 2 \\
43 \cdot 3\end{array}$ & $\begin{array}{l}\times 5.7 \\
14.9\end{array}$ \\
\hline \multicolumn{5}{|c|}{ Carcasses } \\
\hline $\begin{aligned} 40: & \text { A, treated } \\
& B, \text { untreated }\end{aligned}$ & $\begin{array}{l}5 x \cdot 0 \\
49 \cdot 2\end{array}$ & $\begin{array}{l}15 \cdot 0 \\
14.7\end{array}$ & $\begin{array}{l}33 \cdot 2 \\
35 \cdot 5\end{array}$ & $\begin{array}{l}13.9 \\
13.5\end{array}$ \\
\hline
\end{tabular}

The estimates of the total composition of the carcasses are shown in Table 5. It will be seen that the carcass of the treated steer contained about $9.5 \mathrm{lb}$. more bone, $6.7 \mathrm{lb}$. more protein, $28 \mathrm{lb}$. more moisture and $3.4 \mathrm{lb}$. less fat. These differences total $40 \cdot 8 \mathrm{lb}$., 
Table 5. Carcass weight and estimated total contents of moisture, crude protein, fat, and bone in whole carcasses of pair no. $40 \mathrm{~A}$ and $\mathrm{B}$

\begin{tabular}{|c|c|c|c|c|c|}
\hline \multirow[b]{2}{*}{ Pair no. } & \multirow[b]{2}{*}{$\begin{array}{c}\text { Carcass } \\
\text { weight } \\
\text { (lb.) }\end{array}$} & \multicolumn{4}{|c|}{ Carcass composition } \\
\hline & & $\begin{array}{l}\text { Moisture } \\
\text { (lb.) }\end{array}$ & $\begin{array}{c}\text { Crude } \\
\text { protein } \\
\text { (lb.) }\end{array}$ & $\begin{array}{c}\text { Fat } \\
\text { (lb.) }\end{array}$ & $\begin{array}{c}\text { Bone } \\
\text { (lb.) }\end{array}$ \\
\hline 40: A, treated & 780 & $342 \cdot 0$ & $100 \cdot 4$ & $223 \cdot 2$ & $108 \cdot 7$ \\
\hline B, untreated & 737 & 314.0 & $93 \cdot 7$ & $226 \cdot 6$ & $99 \cdot 2$ \\
\hline Difference & +43 & $+28 \cdot 0$ & +6.7 & $-3 \cdot 4$ & +9.5 \\
\hline
\end{tabular}

which is in fair agreement with the difference in carcass weight, i.e. $43 \mathrm{lb}$. Since the carcass of the treated steer was $43 \mathrm{lb}$. heavier and contained rather less fat a less degree of 'finish' must be assumed. The sample cut from the treated animal showed visually a greater area of lean meat and relatively less fat than the cut from the control. It seems probable, therefore, that the extra protein was laid down in the form of muscle.

\section{DISCUSSION}

The determination of carcass composition was made for only one twin pair, but is in agreement with the results of other workers. The increases in the total amounts of bone, protein and moisture and the lack of difference in total fat suggest that under the conditions of this experiment hexoestrol accelerated growth and inhibited the deposition of fat. This would account for the many reports to the effect that the carcasses of treated animals are less well 'finished'. Lack of fat cover in the carcass is not in itself a disadvantage if the public demand is for lean meat, irrespective of quality. The butcher, however, is prepared to pay more for a carcass with a good cover of fat in the right places. It is difficult to see how maximum lean-meat production and quality are to be reconciled in hormone-treated carcasses. The sole object of the feeder is to obtain the best price possible for his product. If, in the eyes of the butcher, the effect of synthetic oestrogens is to lower the quality of the carcass, the feeder must endeavour to overcome this defect. How can it be done? Implantation of the hormone means that the dose once given cannot readily be withdrawn. The encouraging results obtained from the oral administration of hormones (Perry et al. 1955) suggest that a better control of treatment may be possible by that means. It may be that if treatment had been withdrawn after the increased growth had been accomplished and feeding continued for from 2 to 3 weeks more, the undesirable side-effects might have disappeared and heavier and better-finished carcasses resulted. On the other hand, the extra time and food required to 'finish' treated animals might result in a reduction in the efficiency of food utilization. The net return from treated carcasses would then depend on whether the value of the increase in carcass weight would repay the increase in labour and food costs. In any event it is possible that the final result would be an increase in the total amount of meat from treated, compared with control, animals, a possibility that may be of value during periods when meat is scarce. 
The results of this preliminary trial show that much more work requires to be done on the evaluation of the composition of the increased live-weight gains before the use of synthetic oestrogens can be recommended in practice.

\section{SUMMARY}

1. One member of each of five pairs of identical twin steers was implanted with r $20 \mathrm{mg}$ hexoestrol; the other member of each pair was used as control. All animals were given a winter fattening ration consisting of silage, swede turnips, oat straw and a concentrate mixture (ratio of roughage to concentrates approximately $12: \mathrm{I}$ by weight). A sample rib cut was taken from the right side of the carcass of each of one twin pair and analysed for fat, protein, and moisture; from these analyses the composition of the dressed carcasses was estimated by means of regression equations.

2. Treated animals on this high-roughage ration made substantially greater gains in weight and showed better efficiency of feed utilization than the controls.

3. Marked changes in mammary tissue and pelvis such as elevation of the tail-head and elongation of the rudimentary teats occurred as the result of treatment.

4. At slaughter there was no significant difference in dressing out percentages, although they were slightly in favour of the controls. The superficial examination of the carcasses showed little difference in quality between control and treated animals in four of the five pairs. One carcass showed marked deficiency of fat cover compared with the carcass of the control.

5. From chemical analysis of the sample cuts taken from one pair it was estimated that the carcass of the treated animal contained $9.5 \mathrm{lb}$. more bone, $6.7 \mathrm{lb}$. more protein, $28 \mathrm{lb}$. more moisture and $3.4 \mathrm{lb}$. less fat than that of the control.

6. Further research work on the form of administration is required before hexoestrol can be recommended in practice.

We are indebted to Dr J. Davidson for the chemical analysis of the cuts of meat, and to Mr I. McDonald for the statistical analysis.

\section{REFERENCES}

Andrews, F. N. \& Beeson, W. M. (1953). F. Anim. Sci. 12, I82.

Andrews, F. N., Beeson, W. M. \& Harper, C. (1949). F. Anim. Sci. 8, 578.

Clegg, M. 'T. \& Cole, H. H. (1954). F. Anim. Sci. 13, 1o8.

Culbertson, C. C., Burroughs, W., Kastelic, J., Hammond, W. E. \& Cheng, E. (1954). Leafl. Ia St. Coll. agric. Exp. Sta. no. I 94 .

Dinusson, W. E., Andrews, F. N. \& Beeson, W. M. (1950). F. Anim. Sci. 9, 32 I.

Hancock, J. (1951). N.Z. F. Sci. Tech. 33, no. 4, p. I7.

Hankins, O. G. \& Howe, P. E. (1946). Tech. Bull. U.S. Dep. Agric. no. 926.

Jordan, R. M. (1950). F. Anim. Sci. 9, 383.

Jordan, R. M. (1953). F. Anim. Sci. 12, 670.

King, J. W. B. \& Donald, H. P. (1955). F. Dairy Res. 22, I.

Means, T. M., Andrews, F. N. \& Beeson, W. M. (1953). F. Anim. Sci. 12, 176.

O’Mary, C. C., Pope, A. L., Wilson, G. D., Bray, R. W. \& Casida, L. E. (1952). F. Anim. Sci. 1 r, 656.

Perry, 'T. W., Andrews, F. N. \& Beeson, W. M. (1951). F. Anim. Sci. 1o, 602.

Perry, T. W., Beeson, W. M., Andrews, F. N. \& Stob, M. (1955). F. Anim. Sci. 14, 329.

Shanks, P. (I955). Private communication.

Whitehair, C. K., Willis, D. G. \& Bell, M. C. (1953). F. Anim. Sci. 12, 33 I. 